\title{
Fe-, Co- and Cu-Catalyzed Coupling Reactions Using $\mathrm{N}_{2} \mathrm{O}$
}

\section{Key words}

nitrous oxide

iron

cobalt

Oxidative homo-coupling of aryl, alkenyl and alkyl Grignard reagents:

$$
2 \mathrm{R}-\mathrm{MgX} \quad \frac{\mathrm{N} 2 \mathrm{O}}{\mathrm{THF} \text {, r.t. }} \quad \begin{gathered}
\mathrm{R}-\mathrm{R} \\
\text { up to } 99 \% \text { yield }
\end{gathered}
$$

\footnotetext{
$\mathrm{R}=$ aryl, alkenyl and alkyl groups

metal salt $=$ for aryl and alkenyl coupling partners: $\mathrm{Fe}(\mathrm{acac})_{3}$ or $\mathrm{CoCl}_{2}$ $\mathrm{X}=\mathrm{Cl}, \mathrm{Br}$ for alkyl coupling partners: $\mathrm{Li}_{2} \mathrm{CuCl}_{4}$
}

Selected examples:<smiles>Fc1ccc(-c2ccc(F)cc2)cc1</smiles>

$92 \%$ yield<smiles>COc1ccc(-c2ccc(OC)cc2)cc1</smiles>

$96 \%$ yield<smiles>CCOC(=O)c1ccc(-c2ccc(C(=O)OCC)cc2)cc1</smiles>

$50 \%$ yield<smiles>C1CCC(C2CCCCC2)CC1</smiles><smiles>C=C(C(=C)c1ccccc1)c1ccccc1</smiles>

$79 \%$ yield
$\mathrm{Ph}$<smiles>c1ccc(CCc2ccccc2)cc1</smiles>

$81 \%$ yield

Example for the oxidative cross-coupling of Grignard reagents:

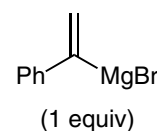<smiles>CC(C)C(C)C</smiles>

(2 equiv)

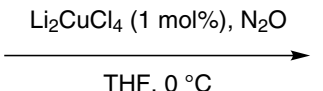

$\mathrm{THF}, 0^{\circ} \mathrm{C}$

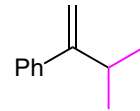

$76 \%$ yield
Significance: For the first time, $\mathrm{N}_{2} \mathrm{O}$ ('laughing gas') is reported to undergo oxidative homo-coupling reactions of Grignard reagents in the presence of metal catalysts under mild reaction conditions. Whereas less than $1 \mathrm{~mol} \%$ of $\mathrm{Fe}(\mathrm{acac})_{3}$ and $\mathrm{CoCl}_{2}$ showed to be superior in the homo-coupling reactions of arylmagnesium reagents, also alkyl Grignard reagents undergo oxidative homocoupling reactions in the presence of $\mathrm{Li}_{2} \mathrm{CuCl}_{4}$.
Comment: The authors applied this new protocol also to oxidative cross-coupling reactions between $\mathrm{sp}^{2}$ - and $\mathrm{sp}^{3}$-hybridized Grignard reagents. Therefore, $\mathrm{PhMgCl}$ and various primary and secondary alkyl Grignard reagents furnish the desired aryl-alkyl cross-coupling products in 59-83\% yield. 